\title{
GATHER THE SCATTERED IN KAILI LAND: Pluralism, Religiosity, and Integration of Central Sulawesi Society
}

\author{
Andriansyah, Syakir Mahid \\ Universitas Tadulako \\ Jl. Seroja No. 1AB, Palu, 94226 \\ e-mail: andrimahid@gmail.com, syakirmahmid@gmail.com \\ Ismail Suardi Wekke \\ Sekolah Tinggi Agama Islam Negeri Sorong \\ Jl. Klamono-Sorong, KM. 17, Klablim, Sorong 98417, West Papua \\ e-mail: ismail@stain-sorong.ac.id
}

\begin{abstract}
Based on the ethnic division of the population, Central Sulawesi Province consists of 12 ethnics groups "original," and many tribal immigrants such as Bugis, Makassar, Java, Bali, and other tribes that have implications for the differentiation of indigenous communities and immigrant communities. The diversity of the tribes is also accompanied by the diversity of their historical background, religion, and culture which might cause friction one another. Based on the existing historical reality, it is showed that the Central Sulawesi region is often hit by ethnic, economic, and religious violences with different intensity. If the diversity among the people of Central Sulawesi is not properly managed, it can lead to disintegration. This article would identify the existence of the plural society in Central Sulawesi and try to formulate the integration efforts of the people of Central Sulawesi.
\end{abstract}

\begin{abstract}
Abstrak: Mengumpul yang Berserak: Pluralisme, Religiositas, dan Integrasi Masyarakat Sulawesi Tengah. Berdasarkan pembagian etnis penduduk, Provinsi Sulawesi Tengah terdiri atas dari 12 etnis asli, dan banyak juga suku pendatang seperti Suku Bugis, Makassar, Jawa, dan Bali yang berimplikasi pada diferensiasi masyarakat asli dan masyarakat pendatang yang berpotensi menimbulkan gesekan antara satu dengan lainnya. Realitas historis menunjukkan bahwa wilayah Sulawesi Tengah sering dilanda kekerasan bermotif etnis, ekonomi dan agama dengan intensitas yang berbeda-beda. Keanekaragaman pada masyarakat Sulawesi Tengah, apabila tidak ditata dengan baik dapat mengakibatkan disintegrasi. Tulisan bertujuan menganalisis keberadaan masyarakat plural Sulawesi Tengah dan mencoba merumuskan upaya integrasi masyarakatnya.
\end{abstract}

Keywords: pluralism, religiosity, Central Sulawesi, integration 


\section{Introduction}

Indonesia, which is known for its cultural diversity, ${ }^{1}$ should consider integration strategies in its plural societies. ${ }^{2}$ Since the fall of the new order, the problem of integration has been the subject of many discussion until now. ${ }^{3}$ This is not separated from the emergence of violent events in various parts of Indonesia which ultimately led to the implementation of development that cannot run in accordance with the plan. ${ }^{4}$ To prevent the occurrence of disintegration of the nation, it is necessary to make concrete efforts, both by the government and society ${ }^{5}$. If not, then the slogan of 'Bhineka Tunggal Ika', on the emblem of the State of Indonesia, will only be a dream, without any direct evidence that can be done by the people of Indonesia. ${ }^{6}$ Many ways can be done to anticipate the disintegration, among others are through social, political, cultural, economic, and educational approaches. ${ }^{7}$

Central Sulawesi, as a part of Indonesia, has tribal, religious, and cultural diversities. The ethnic inhabitants of Central Sulawesi consist of twelve indigenous tribes enriched with the presence of tribal immigrants such as Bugis, Makassar, Java, Bali, and others. The diversity of the tribes is also accompanied by the diversity of historical background, religion, and culture of each ethnic supporters. Therefore, the implementation of development in Central Sulawesi must be carried out jointly by the people, without having to discriminate between tribes, religions, and races.

Based on the existing historical reality, Central Sulawesi is often conflicted about economic, political, ethnic, or religious motives. ${ }^{8}$ Up to now, the conflict still continues to

${ }^{1}$ Sitti Murni Kaddi, et al., "Kerukunan Keluarga Sulawesi Selatan (KKSS) sebagai Forum Komunikasi dalam Penyelesain Konflik Etnis di Kota Palu," in Jurnal Komunikasi Kareba, Vol. 2. No.1 Januari-Maret 2013, p. 81-89; Ismail Suardi Wekke, "Integrasi Pendidikan Islam dan Pembelajaran Kewirausahaan di Pesantren Minoritas Muslim," in Fenomena, Vol. 9. No. 1, 2017, p. 1-23.

${ }^{2}$ Widiastuti, "Analisis Swot Keragaman Budaya Indonesia," in Jurnal Ilmiah Widya, Vol. 1 No. 1, 2013, p. 8-14.

${ }^{3} \mathrm{H}$. Mahid, "Kekerasan Massal dan Pluralitas Budaya," in Jurnal of Midden Celebes, Vol. 1. No. 2, 2012, p. 5-15; HS Ahimsa-Putra, "Kemajukan Budaya, Komunikasi, dan Integrasi Nasional," in Journal of National Resistance, Vol. I. No. 1, April 1999, p. 31.

${ }^{4}$ Nur Ainiyah, "Pembentukan Karakte Melalui Pendidikan Agama Islam," in al-Ulum. Vol. 13, No. 1, Juni 2013, p. 25-38.

'Zainal Said, "Konflik Sosial Keagamaan Islam Non-Mainstream dalam Masyarakat Majemuk di Indonesia," in al-Ulum, Vol. 12, No. 2, Desember 2012, p. 419-436.

${ }^{6}$ Gina Lestari, "Bhinnekha Tunggal Ika: Khasanah Multikultural Indonesia di Tengah Kehidupan Sara," in Jurnal Pendidikan Pancasila dan Kewarganegaraan, Vol. 28. No. 1, Pebruary 2015, p. 31-37.

${ }^{7}$ Cholichul Hadi, et al., "Entrepreneurship and Education: Creating Business Awareness for Students in East Java Indonesia," in Procedia-Social and Behavioral Sciences, Vol. 177, Juli 2014, p. 459-463.

${ }^{8}$ Heri Cahyono, "Pendidikan Multikultural di Pondok Pesantren: Sebagai Strategi dalam Menumbuhkan Nilai Karakter," in At-Tajdid, Vol. 1. No. 1, Januari-Juni 2017, p. 26-43. 
haunt the people of this region. Various unrests, such as clashes between ethnic groups, to the widespread of religious groups (which intensified after the reformation was docked) colored the dynamics of Central Sulawesi. Those clashes affect the life of people in this region, as they directly shake the bonds of unity in the social life. The outbreak of the clashes is not an instantaneous thing, but an accumulation of the sediment of various anxieties buried in the mind and the heart of the society. Therefore, it is necessary to formulate a strategy to create integration among the people of Central Sulawesi.

The discussions on pluralism, especially in Indonesia, mostly focus on the conceptual level which emphasis on religious diversity. ${ }^{9}$ The discussion at the conceptual level ultimately often ignores the empirical reality and does not touch the sensitive aspects of the problem of pluralism, such as economic control and the struggle for political power, which often lead to friction and violence to the plural society structure. In this case, the researchers tries to fill the void by looking at the reality of the plural society of Central Sulawesi, the accompanying conflicts and the integration effort. This paper is not intended to provide a single recipe for what to do with a pluralistic integration effort, but rather to give an idea of what can be done, so that the purposes can be achieved. This paper used a cultural approach as an attempt to achieve integration within the pluralistic community of Central Sulawesi. Furthuremore, this research used pluralism in religion and ethnicity

\section{Method}

This study applied a historical approach to see what do the realities and dynamics of pluralism like, especially economic domination, the struggle for political power, and a lack of understanding of local culture in Central Sulawesi. To enrich explanations, a set of concepts derived from other social sciences such as sociology and anthropology was used in this paper, especially in formulating efforts to achieve the integration of the plural society of Central Sulawesi. Meanwhile, the data source used emphasized on archive studies, documents and interviews. Furthermore, after the data collected, data analyses were performed using qualitative analysis methods.

\section{Plurality in Central Sulawesi: Ethnicity and Capital Mastery}

The people of Central Sulawesi is one of the forms of plural society in Indonesia. It can be seen from the socio-cultural condition of this region which is inhabited by twelve ethnics, they are: Kaili, Tomini, Kulawi, Lore, Pamona, Bungku, Mori, Saluan, Balantak,

${ }^{9}$ M. Azhar, "Masyarakat Kitab dan Pluralisme," in Journal of Tarjih, Vol. 11. No. 1, 2013, p. 51-59; Ryandi, "Antara Pluralisme Liberal dan Toleransi Islam," in Kalimah Journal, Vol. 11. No. 2. 2013, p. 252-270; U. Hanik, "Pluralisme Agama di Indonesia," in Tribakti Journal, Vol. 25. No. 1. 2014, p. 153. 
Banggai, Buol, and Toli-toli. ${ }^{10}$ Not to mention some indigenous tribes (who use different languages) that inhabit the inland areas. The original ethnic groups are scattered in various areas of Central Sulawesi. ${ }^{11}$ Kaili people, for example, inhabit the region of Donggala District, Parigi Moutong, and Palu City. Meanwhile, Kulawi inhabit the district of Sigi and use the language Kulawi-Lindu and Pipikoro language. Then, there are also Lore people who use three different languages, namely Tawaelia, Napu, and Bada who inhabit the district of Poso. On the other hand, the Pamona ethnic who inhabit the Poso City, Poso Pesisir, Una-Una, Walea Islands, Lage, North and South Pamona, Ampana Kota, Ulubongka, and Tojo. The Mori ethnic who use Mori language inhabit the Upper and Lower Mori regions, as well as the Petasia which is located in North Morowali District. Then, there is Bungku ethnic who inhabit Bungku West, Central, North, and South, and Menui Islands in Morowali District.

In the eastern part of Central Sulawesi, there are 3 (three) major ethnic groups, namely Banggai, Saluan, and Balantak that are known as "babasal". The three ethnic groups are scattered in Luwuk District and Banggai Kepulauan Regency. Then, in the northwestern part of Central Sulawesi, live Buol and Tolitoli. Buolese, who use Buol as the language for conversation, can be found in Palele, Bunobogu, Momunu, Bokat, and Biau District of Buol, while ethnic Toli-toli can be found throughout Tolitoli District.

Long before the independence of Indonesia, each ethnic group had its own traditional system of government and territory, such as Banaga Kingdom, Sigi Kingdom, Palu Kingdom, Poso Kingdom, Napu Kingdom, Tojo Kingdom, Togian Kingdom, Parigi Kingdom, Moutong Kingdom, Mori Kingdom, The Kingdom of Bungku, the Kingdom of Banggai, the Kingdom of Toli-Toli, and the Kingdom of Buol. Each of those ethnic groups also has distinctive customs characteristics, among others are: a) clothing; b) typical food; c) life cycle ceremony; d) housing; and e) the language dialect. In addition to the original ethnic groups as mentioned above, the Central Sulawesi region is also spread over various other tribes, for example: Bugis, Makassar, Mandar, Java, Bali, China, Arab, and so on. Each of those ethnic groups embrace various religions, such as Islam, Protestant Christianity, Catholic, Hinduism, Buddhism, and Confucianism.

The ethnics belief system in Central Sulawesi begins with the worship of spirits considered to possess the power that can bring goodness and evil for human life. In addition, the minds of the people of Central Sulawesi are overwhelmed by the forms of worship of the unseen forces that exist in the natural surroundings, such as large trees, rivers, oceans, large stones, soil, wind, fire, and others. The emergence of beliefs about the existence of the inhabitants or rulers of the jungles, rivers, rocks, seas, and so on make humans not to spoil the forest,

${ }^{10}$ A.C. Kruijt, "Het Ijzer In Midden Celebes," in Journal of Bijdragen Tot De Taal Land-En Volkenkunde Van Nederlandsch-Indie, Deel 53. 1901, p. 148-160.

${ }^{11}$ Leo Agustino Halidi, "Pemikiran Politik Lokal dalam Sejarah Pembentukan Provinsi Sulawesi Tengah," in Jurnal Analisis Politik, Vol. 1. No. 2, Maret 2016, p. 9-23. 
and catch fish in rivers or in the sea without any ceremony. The worship of the spirits and the forces of nature gradually began to be abandoned when Islam began to spread in Central Sulawesi in the $16^{\text {th }}$ century. Then, in the $19^{\text {th }}$ century, with the arrival of the Dutch missionaries, some of the people of Central Sulawesi chose to be Christians, especially the ones live in the hinterlands, such as Poso, Napu Valley, and North Morowali. The existence of a Hindu population in Central Sulawesi is generally embraced by the transmigrants originating from Bali. The religion that is the least adhered by the people of Central Sulawesi is Buddhism. Generally, the adherents of this religion are the descendant of ethnic of Chinese, but among them there are also belief in Confucian religion.

The existence of other tribes (immigrants) in Central Sulawesi bring also their cultural identities. In the development, each of them then formed organizations of their communities, for example, Kerukunan Keluarga Sulawesi Selatan - KKSS (South Sulawesi Family Harmony) for the migrant residents from South Sulawesi, Kerukunan Keluarga Sulawesi TenggaraKKST (Southeast Sulawesi Family Harmony) for the migrant residents from Southeast Sulawesi, Kerukunan Keluarga Indonesia Gorontalo - KKIG (Indonesian Family Harmony Gorontalo) and LAMAHU for the residents from Gorontalo, Ikatan keluarga BanyumasanIKABA (Banyumasan Family Association) for the people of Central Java, precisely Banyumas and surrounding areas. Margisa Luyu, the community for Sundanese, Eko Wandowo is the gathering for Javanese and Sundanese, then there is also the Mataraman Family Association which is the gathering of families from southern Central Java and Yogyakarta, as well as many other paguyuban. The establishment of paguyuban each tribe is increasingly complement the dynamics of life of the people of Central Sulawesi.

Theoretically pluralism is a concept that explains the ideology of power equality in a multicultural society in which power is equally divided among the various ethnic groups so as to encourage mutual influence among them, and the multicultural society may enjoy the rights equal and balanced, who can pick and protect themselves because they practice culture. ${ }^{12}$

Pluralism describes the fact that in society there are unspeakable ethnic groups into their ethnic cultural identity in general, this group has different behaviors for example; speaking in a different language from his ethnic tongue, embracing a religion different from the majority of the religions in which the ethnicity, etc. ${ }^{13}$ And the formation of pluralism that becomes the structure in society that describes cultural differences among ethnic

${ }^{12}$ Milton M. Gordon, "Models of Pluralism: the New American Dilemma," in Annals of the American Academy of Political and Social Science, Vol. 454 March 1981, p. 183; R. Bernstein, "Cultural Pluralism," in Philosophy \& Social Criticism, 41(4-5), p. 347-356.

${ }^{13}$ Shuyan Zhao, "Theoretical Construction of Freedom and Pluralism Education in Pastoral Areas," in Journal International Education Studies, Vol. 2, No. 2 May 2009, p. 90-98; Azyumardi Azra, et al., "Pesantren and Madrasa: Muslim Schools and National Ideals in Indonesia," in Robert Hefner and Muhammad Qasim Zaman (ed.), Schooling Islam: The Culture and Politics of Modern Muslim Education (Princeton, New Jersey: Princeton University Press), p. 172-198. 
groups and the difference lies only in the area of social structures that have the same cultural elements with their dominant culture always appear with a particular culture (subculture) separate from the dominant group. ${ }^{14}$

Ethnic composition with all their pranata (institutions) as described above can be a picture of how diverse the variety of cultures owned by the people of Central Sulawesi. The diversity ultimately forms a pluralistic society. ${ }^{15}$ Plural societies have characteristics of physically adjacent life groups, but they are fragmented because of the social differences and are not incorporated into a political unit. Every individual in a plural society, especially in certain contexts and situations, is always affiliated with two important factors, horizontal and vertical factors. Such affiliations are essentially the main shaper of ethnicity in today's society. The horizontal factors consist of: (1) ethnic and genetic origin; (2) regional languages; (3) custom or behavior; (4) religion; and (5) clothes/food, and other material cultures. Meanwhile, the vertical factors are (1) income (economy); (2) education; (3) settlement; (4) work; and (5) socio-political position. ${ }^{16}$

Nowadays pluralism is becoming polemic in Indonesia because of the fundamental difference between pluralism and its initial sense of pluralism that means: (1) Pluralism is overwhelmingly religious, not just socially cultural. (2) Pluralism is used as a reason for mixing between religious teachings. (3) Pluralism is used as an excuse to change the teachings of a religion to suit other religious teachings. ${ }^{17}$ If looking at the idea and context of developing connotations, it is clear that pluralism in Indonesia is not the same as pluralism as it is in English. And it is not strange if this condition provokes reaction from various parties. The conflicts that occur are more confusing because of the existence of ambiguity of the language. Just as a person pronouncing pluralism in a non-assimilationist sense is confused when it comes to pluralism in the sense of assimilation. Already should appear an alignment of opinion so as not to arise confusion. ${ }^{18}$

Based on the polarization of access to sources of income, those ethnicities play a significant role in certain areas. Ethnic Gorontalo for example, they mostly work in the

\footnotetext{
${ }^{14}$ Zainal Abidin Bagir, and Suhadi Cholil, The State of Religious Pluralism in Indonesia: A Literature Review (Yogyakarta: Center for Religious and Cross-Cultural Studies, Gadjah Mada Univeristy, 2008).

${ }^{15}$ Piers Gillespiem, "Current Issues in Indonesian Islam: Analyzing the 2005 Council of Indonesian Ulama Fatwa No. 7 Opposing Pluralism, Liberalism, and Secularism," in Journal of Islamic Studies, 18 (2), 2007, p. 202-240.

${ }^{16}$ Gordon, "Models of Pluralism," p. 347-356.

${ }^{17}$ Amy Freedman and Robert Tiburzi, "Progress and Caution: Indonesia's Democracy," in Asian Affairs: An American Review, 39, 2012, p. 131-156; Riaz Hassan, "On Being Religious: Patterns of Religious Commitment in Muslim Societies," in The Muslim World, 97, (3) (July 2007), p. 437-78.

${ }^{18}$ Robert Hefner, "Islamic Schools, Social Movements, and Democratization in Indonesia," in Robert Hefner (ed.), Making Modern Muslims: The Politics of Muslim Education in Southeast Asia (Honolulu: University of Hawaii Press. Human Rights Watch, 2011).
} 
field of education, judiciary, and economy. The Javanese and Balinese ethnics who came to Central Sulawesi in large numbers through the transmigration program, in the development, played a role in the military and the informal economy sectors. Another case of the Minahasa ethnic (Manado), they are widely spread in the banking, entrepreneur, and governmental (bureaucrats) sectors. Meanwhile, Chinese and Arab ethnic, both with the status of foreigners (Warga Negara Asing, WNA) and Indonesian citizens (Warga Negara Indonesia, WNI) play an important roles in the economic field, especially in the formal economy sectors. Furthermore, the Bugis people almost fully have control on market economy in Central Sulawesi. Meanwhile, the most indigenous people struggled in the informal economy sectors.

Therefore, it is clear that there is ethnic polarization in accessing the sources of income in Central Sulawesi. This condition affects two things: First, the emergence of synergy and interdependence between an ethnic and other ethnics, which eventually led to an economic links which accumulate and involve all existing ethnics. In fact, seeing the reality of the arrival of Javanese transmigrants in the Kulawi area in 1971 which influenced the work ethos of the peasants in Kulawi. Likewise with Bugis, Bali, and Javanese immigrants in Kasimbar sub-district; Second, the emergence of unequal relationships due to various factors such as capital, government policy, education level, and various things that led to the occurrence of discriminatory actions and marginalization of a particular ethnicity.

\section{Plurality Problems and Rupture of Communal Violence: Cases in Poso and Salena}

In pluralistic societies, diversity can often trigger social events in society, moreover, the dichotomous views of indigenous and immigrant communities. If this conception is misunderstood, it can lead the society to a division. The outbreak of conflict or mass violence will surely happen if the conditions that support the occurrence of that occur.

In the period of the late 1990s and early 2000s, the interethnic and religious violences in Central Sulawesi reached its peak. Unimaginable events of violence that have become unpredictable became national, and even international issues. The inter-religious violence that took place in Poso became the most talked-about case. This event brought down a series of events that the atmosphere can still be felt until now. Poso is a fairly quiet coastal town in Central Sulawesi province before the riots occurred. For Christians, December $24^{\text {th }}, 1998$, was a Christmas Eve, while for Muslims, the date is right in the middle of the fasting month of Ramadan. When a Christian teenager from the Protestant neighborhood of Lombogia stabbed another teenager from the Muslim community from Kayamanya, the riot erupted in the city of Poso. Soon, everyone agreed that the source of the problem was alcohol and the problem was forgotten.

April, 2000, a more serious violence erupted in the City which soon spread to the Poso District. May, 2000, Christian forces massacred about eighty Muslims in a small Muslim 
enclave which the shelter was in a mosque called Walisongo, not far from the south of Poso City. Their corpses were found in the river behind the mosque. In July, 2001, Muslim militants from Java came to help their brothers. January, 2002, four months after the September 11 Attack in the United States, Poso was mentioned in New York Time. The US Deputy Secretary of Defense, Paul Wolfowitz, explained that "Muslim terrorists" have found "a little corner for themselves" in Sulawesi. The conflict escalated from a local dispute into an international problem. Thousands fatalities and hundreds of houses of worship and dwellings burned. Various researchers concluded that the outbreak of communal violence cases in Poso occurred because of the seizure and competition over political and economic power based on ethnicity. Aditjondro even concluded that the conflicts in Poso involved the marginalization of Indigenous people in Poso, not religion.

Communal violence occurred in Central Sulawesi was not only related to interethnic power and economic struggles, but also about the narrowness of understanding of the local cultural diversity. The most obvious case example in this case was the Madi incident in Salena. October, 2005, the people of Indonesia, especially Central Sulawesi, were overwhelmed by the news of the deaths of some members of the police force when they were about to negotiate against Madi and his followers who joined the "Perguruan Dente Sepuluh" association in the Salena village, an area located in the suburban mountains of Palu, Central Sulawesi.

Many people think that Madi and his followers are deviant sect followers. Issues of the deviant sect quickly spread to involve the police to participate in handling the case. Unfortunately, without carefully studying the form of Madi movement, the police immediately deployed the troops to interrogate Madi in Bantaya, where Madi and his followers gathered. The arrival of the police provoked the anger of the Madi group who were conducting Balia ritual (treatment) attacked the police who were there.

Teaching practiced by Madi and his followers were actually a blend of Islam with traditional beliefs. It is a part of the mystical religious teachings as a local variation on the development of religious teaching. Madi's invitation to stick to adat was also followed by most Salena communities. Their lack of knowledge about Islam was one of the factors influencing the development of an old culture containing animist values. The belief spread especially in remote areas and isolated tribes such as in the Gawalise Mountains, including Salena. In the implementation of Balia ritual of treatment, Madi, who played Sando (shaman) was often possessed. The ritual was a magical ceremony that aimed to be a means of healing or rejection of a disease, a request for protection to the supernatural power that was considered as the source of providers, salvation, as well as can provide havoc to humans. In the Balia treatment system, Sando's role is dominant because he acts as the person who communicates both directly and indirectly with the spirits of the ancestors, spirits, and other magical powers. When a sando is possessed by a spirit, all his actions and deeds change. Under such conditions, Salena people believe that Madi was someone who had a special ability as a connection between the human nature with the spirit realm. 
Salena's geographical condition in the mountains causes the region far behind from other communities in Palu. Although they already knew about some religions (Islam and Christian), the animist beliefs were still deeply rooted in the tradition of the mountainous Kaili community, so many people still practice the teachings of religion that mixed with traditional beliefs. This condition was further supported by the lack of attention by the government. The remote areas in the mountains have not received good facilities like in the city of Palu. The development was still far from expectations. Almost no education facilities, especially the one related to health, in the region. Under such conditions, most of the Salena people were poor and unable to choose other alternatives by becoming followers of Madi who was expected to be capable to bring change to their lives.

\section{Gather the Mosaic Flakes: Integration Strategy of Central Sulawesi Community}

Looking at the depiction of plurality and the various conflicts that accompany it, it is indispensable for integration efforts as a preventive form for massive fraction and violence to not reoccur in the future. The integration efforts can be undertaken by intensifying the diverse dialogue forums among the community groups to build a more pluralist and inclusive understanding, to educate them about pluralism, the importance of peace, and religious tolerance through schools.

Based on the examples of cases of communal violence as described above, it is necessary to build special measures as an effort that the people are not easily provoked to engage in conflict with other ethnics or religious groups. Therefore, the following steps are important to be implemented. First, the redevelopment of an exclusive community diversity paradigm becomes inclusive. This step can be done through schools, religious activities, and through interfaith dialogue forums. Through these steps, it is hoped that they will be gradually able to provide new insights and information on the inclusive diversity understanding. The spirit of inclusiveness is not aimed at confusing religious teachings (aqidah) which should not be mixed up, but rather aimed at eroding a rigid, exclusive diversity of understanding, which is the understanding of diversity that assumes that our religion is the most correct, while the other religion is utterly wrong. With the spirit of diversity that is inclusive and moderate, it is expected to be able to cultivate the spirit of cooperation socially, politically, economically, and others among the followers of different religions.

Second, building law awareness of community that emphasizes all issues in society must be settled based on the ties of kinship and legally. Building this legal awareness is essential to prevent conflict from continuing. The development of legal awareness as a preventive action to resolve conflicts can be done through schools, religious institutions, and government. Third, the need to build political awareness of the community. This step is important to make people can be more critical in looking at the various problems occur. This step is expected to build a critical awareness of the community in order to see the political and economic interests behind various ethnic and religious issues. 
By developing the more humanist, pluralist, and contextual diversity of understanding, it is expected that the universal values that exist in religions such as truth, justice, humanity, peace, and integration in Central Sulawesi can be upheld. More specifically, it is meant to maintain harmony and peace between the religious believers. Reality can even be seen from an incident that occurred in January 1951 in which Bestuurs-Assistant Hadji Abbas ordered one of the youths of Tomini tribe and Gorontalo tribe to lift his belongings from Port Moutong to be escorted to his home. A few moments later the youth from the Tomini tribe cursed youths from the Gorontalo tribe with harsh words, "You are a Gorontalo people are brash", so there was a dispute that almost resulted in a fight between the youths of both tribes who were at the port. Both sides had even armed themselves with sharpened bamboos. Fortunately, the tension was successfully muted by Bugis-Tomini tribal leaders headed by Ando Alhabsjie and the tribe of Gorontalo headed by Ali. However, the dispute between the two tribes was heated up with the flyers posted on the flagpole in front of the Kopra Foundation Warehouse in Moutong on January 20, 1951. It was found that the leaflet contained insulting and threatening sentences against the Gorontalo tribe. The Gorontalo tribesmen in Moutong then reported the matter to the Moutong District Chief. This issue was then forwarded to the Head of the State Administration in Parigi who immediately asked both disputing parties to make a peace agreement; however, the party of Gorontalo tribe was apparently not at all satisfied with the advice, so they continued to object to the leaflet.

In the Dutch Colonial period, Poso became one of the fertile fields for the most successful Christian mission in Dutch Hinda. In 1892, Dutch Protestant missionaries, Kruyt and Adriani arrived in Poso and began to use an ethnographic approach in carrying out the Christianization mission in that region, although their efforts were in no way separated from the colonial project. The harvest of their greatest souls was obtained after a bloody campaign in 1905, after the people of the mountains decided to embrace the religion of the new rulers. Christian identity that emerged from the traumatic moment of the colonial state was represented by the loyal teachers, church elders, and the resulting government employees. A similar process has occurred among many other tribes in the archipelago that coincided with Dutch colonial penetration. The Christianization within the local population in Poso became the most important part of the period of Christian identity formation in the region. When Japan replaced the Dutch occupation of Indonesia in World War II, the majority of the local inhabitants of Poso living in the highlands were more closely connected socially and economically with Protestant missionaries and Dutch colonial regimes than with Muslim groups on the coast.

After Indonesia's independence, the government continually increased its presence throughout the 20th century in various regions. Under the New Order, the pace of state penetration was accelerating. The urban economy was the most important part of the economy of the society, which consisted of trade and the government sector. In Kabupaten Poso, government money was even more important than trade. In the New Order period, 
state-sponsored development changed the landscape around Poso. The gradually built Trans-Sulawesi Highway was finally completed in the early 1990s linking the provincial capital of Palu on the west coast with Palopo in South Sulawesi, and further with all points in south of Makassar. The new road passed through the city of Poso and pierced the heart of the Christian area of Lake Poso to the south, a rural haven from the 1980s. Along the way, migrants came from outside the regency. Some of the state-sponsored migrants came from far-flung Java, but more migrants were coming from South Sulawesi closer. Government figures show that at the end of the New Order, Poso Regency had the highest proportion of migrants in the Province.

The problem first arose when the migrants began to control the land that the local people regarded as their own land according to custom, but by formal law it was considered idle land. Commercial crops began to be planted as prime commodities mainly by migrants and also by local people who slowly replaced subsistence farming. The increasing amount of money circulating in rural areas stimulated social mobility and narrowed the gap that was used to distinguish between rural and urban.The most serious complaint in the countryside outside the city of Poso was that the local peasants in the mountains were quickly lost their ulayat lands fell into the hands of highly privileged trading farmers. Chocolate was booming for a decade when the monetary crisis of 1998 made chocolate prices rise. When that happened, many new people jumped into the business. Soon the chocolate gardens filled the sides of the hill along the new road connecting Poso with Palu. However, not everyone had the means to do the same, and for Poso local farmers, the chocolate boom did not bring in a bonanza.

The chocolate plants quickly created classes of rich peasants and poor peasants. Some wealthy farmers are local people who are able to adapt to the on going economic situation, while most of the others are outsiders who came later and managed to gain control of the land. The prominent people among the people mentioned recently were transmigrants of Bugis tribe from South Sulawesi. The local poor people of Poso became more burdened with debt and often had no land to pass down to their children. Even sometimes the uneven boom of chocolate led to violence. Not far from Poso in Luwu, South Sulawesi, complaints about uneven gains for poor farmers played an important role in repeated local disputes. Here too highly entrepreneurial entrants (the Toraja people) were one element in a complex mix between economic, ethnic, and political aspects. The migrants who came to settle and then attempted to gain dominant power over the territory that the local people regarded as their "bloodland" had caused much indignation. This pattern was almost even happening throughout Indonesia. This is one of the reasons why the World Bank in 1988 stopped funding for new transmigration.

Some of incidents of violence that occurred in Poso could also be traced up to complaints about chocolate plants. Nevertheless, chocolate was not the only source of contention in Poso. The expansion of capital into logging of ebony forest and sand mining has caused 
protests and complaints of the poor people of Poso to migrants. Chocolate, deforestation and - the most fundamental - problem of the land, have helped to intensify the fighting in Poso.

In addition to land tenure, the arrival of transmigrants in Poso also led to a demographic shift towards the majority of Muslims which resulted in Christians never becoming a majority in Poso Regency. In Central Sulawesi province, the largest number of Christians was in Poso District, but with the arrival of transmigrants, the number of Poso Christian populations shrank marginally from $38 \%$ in 1980 to $32 \%$ in 2000 . What were more troubling than this gradual social shift were the sudden political changes that followed President Soeharto's resignation in May 1998. Christian and Muslim parties were easily trapped in the seizure of political power when the reforms had just been dug up. Each group was competing to master strategic positions in the local government of Poso. As a result, economic struggles and protracted power struggles in Poso were accumulated in the eruption of the bloody conflicts in Poso during the early years of 2000.

\section{Feeling Easy to Label 'Deviant': a Case in Salena}

The problem of plurality was not only always rooted in the issue of mastery of livelihood resources by migrant groups. Problems could occur because of a lack of understanding of the local culture that is an integrated part of a local community. This can be seen from an event in October 2005 in which the Palu community, even Indonesia, was rattled with news of the deaths of some members of the police when they were about to negotiate with Madi and his followers who were members of the "Perguruan Dente Sepuluh" association in Salena Hamlet, an area located in the mountainous suburb of Palu City, Central Sulawesi.

Madi who had expertise as Sando (shaman) was able to influence people in the region and played an important role in the bloody event that occurred in Salena. Salena is a village in Buluri Village, Palu Barat Regency, Palu City, Central Sulawesi. Salena was divided into two parts, namely Salena and Salena Bolonggima. In the administrative government of Palu City, Salena is known as Salena I and Salena Bolonggima known as Salena II. Salena Bolonggima (Salena II) became the site of Madi to form his community atop the ranks of the Gawalise Mountains that were so isolated.

The majority of the Salena people were of Kaili sub Inde. Kaili tribe was the largest ethnic group in Central Sulawesi and consisted of several sub-ethnic groups that used different dialects. Despite having a different dialect, Kaili people generally understand other dialects. Kaili Ledo was used as a language of unity (Linguafranca) among Kaili people.

Based on the geographical location of the settlements, Kaili people could be divided into three groups: 1) The Kaili Coastal People, that is the Kaili who settled on the coast, namely the shores of Makassar Strait, Palu Bay and Tomini Bay; 2) The Kaili Hinterland People, the Kaili people whose settlements were located in the hinterland, especially in 
the Palu Valley; 3) The Kaili Mountains People, the Kaili who settled in the mountains, such as the Gawalise Mountains (Verbeek Mountains), the Fennema Mountains, and along the mountains between the West Coast and the East Coast, Donggala Regency.

Coastal Kaili people generally work as farmers, fishermen and government servants. When compared to the Hinterland Kaili and Mountains Kaili, Coastal Kaili is relatively faster in accepting changes and modernization, because it is easy for them to make cultural contact with the outside world. Meanwhile, Kaili people living in mountainous areas lived with very minimal and underdeveloped facilities. Their education level was very low. Most of the population was not yet educated while the highest level of education, only up to junior high school. There was only an elementary school in Salena located in Salena I. If they want to continue their education, Salena people must go to mother Village, that is, Buluri Village. Development in Salena was very far from expectations. Prior to the Salena event, there was no health facility at all.

Since the mid-seventeenth century (circa 1650s), Islam has entered the area of Palu and its surroundings. The person who spread Islam is a scholar from Minangkabau named Abdullah Raqie better known as Dato Karama. He brought along his family and followers who numbered about 50 people and then settled in Palu. They managed to Islamize the people of Palu and its surroundings. The first ruler who was willing to accept the teachings of Islam was I Pue Njidi, a ruler of Kabonena region. Islamic teachings were growing and institutionalized by the presence of an Arabic figure named Sayyid Idrus bin Salim Aldjufrie. He then settled in Palu and founded Alchairaat Islamic College on June 30, 1930. However, the pattern of Islamic development conducted by Alchairaat and by the government had not given much attention to the community in the mountains. Therefore, even though Salena's people had embraced Islam, but the influence of customs was still very strictly enforced. It can be seen that there were eleven traditional ceremonies that were still practiced by Salena residents, namely: (1) Polama, a traditional ceremony intended to appeal to God to give safety and health to their children who are still in the womb of the mother; (2) Mounju, a traditional ceremony to invoke and thank for the blessings of God to give fertility to their crops and to give good results; 3) Nobau, a traditional ceremony in order to be grateful for being given their health and descent. This ceremony is performed by a person who already has more than one child or a second baby has been born; 4) Nokeso, traditional ceremony to ask for the safety of the daughter. The ceremony is especially praying for girls; 5) Nompepoyu, traditional ceremony when going to the opening of fields or gardens; 6) Nompakoni, a traditional ceremony when going to gardening and to be given fertility to the soil; 7) Nompadokaya, a traditional ceremony for the safety of logged-out timber; 8) Balia, a traditional ceremony in order to be grateful and as the healing of the sick (Medicine); 9) Nombarea, a traditional ceremony to be grateful for the newly harvested rice fields. This event was held three days before harvest; 10) Nompaliu, a traditional ceremony to be grateful for the harvested fields; 11) Movunja, traditional ceremony to ask blessings to God. 
As a society that still adheres to customary values, Salena society consisted of several social layers, namely (1) Village customary elders (Togurana Nu Ada) and Sando (shaman/ healer); (2) The clergy; (3) State bureaucrats, namely Head of Hamlet and Head of Neighborhood (RT); and (4) General community (Ntodea). The slavery system had gone. The social stratification shows that Madi was one of the elites in Salena Hamlet, because he was a Sando (shaman). After the bloody event of Madi, there was a shift in the social structure of society in Salena, namely: (1) State bureaucrats, namely the Head of Hamlet and Head of Neighborhood (RT); (2) The clergy; (3) Village customary elders (Togu rana $\mathrm{Nu}$ Ada) and Sando (shaman/healer) and (4) General community (Ntodea).

The Salena people are mostly poor or disadvantaged. Salena residents generally had livelihood as farmers with commodities of corn and sweet potatoes that the results they sold to the market and consumed for the purposes of daily living. The various economic, socio-cultural and educational issues they face were the most important issues to be considered in the area in order to be like the people in the coastal and urban areas. Salena hamlet was still far behind, in terms of economic, educational and other social welfare. There was a huge disparity in various aspects between Salena residents who ironically administratively still be part of the city of Palu together with most residents of Palu City.

The desire of the Salena people to live a prosperous life like the people who live in the coastal and urban areas led to the actions or movements that they did to claim their rights as a society which should also be considered. A number of aspirations were also expressed to the government in demanding these rights. The Salena community recorded a number of demonstrations from 1999 to 2004. The demands on development, indigenous peoples, neighborhoods, and health care were the issues they addressed. September 1999 they demanded the repair of residents, highways, mosques, and schools. Then, December of 2000 they again demanded road repairs due to the increasingly severe condition. Around 2002, they demanded the settlement of indigenous issues in Salena, while in June of 2003 the people of Salena complained about health because many people, at that time, suffered from diarrhea. October 2004, Salena residents went to the Palu City DPRD office, protesting against the construction of PDAM water tanks and collecting pledges of facilities and facilities and infrastructure repairing to a number of legislative members (DPRD Kota Palu) re-elected.

Madi was born on 23 April 1977 in Hamlet Salena, Buluri Village, Palu Barat Regency. His father, Sani Kampu, worked as a farmer who died from hanging himself, while his mother was named Minggu. Madi was the sixth of eight children. Madi's father, Sani Kampu was the son of Nanja and Dingi's couple. As for Madi's Mother, she was the daughter of the couple Bangu and Rinalusu. Bangu (Madi's Grandmother), was also known as a Sando (shaman / healer) in Salena Hamlet and very proficient in healing the sick. Madi married a woman named Marni born in 1979. From her marriage, Madi was blessed with five children named Ela, Gafur, Safari, Fian, and Maran. If observed from the background of his family, Madi comes from a family with a homely life. The death of Madi's father by 
hanging himself showed that Madi had a family background that is "problematic". The science of shamanism owned by Madi was inherited from his grandmother who also worked as Sando (shaman/healer).

Madi had attended elementary school (SD) in Salena and graduated in 1991. He then continued his education to Madrasah Tsanawiah Alkhairaat (MTs) Buluri. At the time of continuing to junior high school, he did not graduate and only until the second grade only. This was due to economic factors that did not support. During Madi's education in Buluri, he stayed with Amirudin (the main witness before the clash in Salena). According to his schoolmate at MTs, Madi was known as a quiet person. Behind being quiet student, he was also a polite, kind, and intimate student in friendship so Madiwas liked by friends very much.However, according to information from the school MTS Buluri, Arifin a.k.a. Madi never went to school in that place. Madi in question was another Madi, not a criminal in Salena. This informationwas obtained after checking directly at the MTS Buluri School by the Executive Board of Alchairaat Center of Palu. The rejection of the Supreme Commander Alchairaat can be regarded as an attempt to "wash hands" over Madi Movement. If it is true that Madi is a former student of Alchairaat, then the reputation of the largest Islamic mass organization in Central Sulawesi region would surely be tarnished and considered failed in doing "Islamic education", especially in Palu.

Madi had worked as an honorary officer of Palu City as cleaner for several years. After stopping, he returned to gardening and farming in Salena with corn and tubers commodities. Madi also worked as an orchid searcher to sell them in Palu City to support his family income. The profession that made Madi famous is as a sando (shaman) because of his ability to heal the sick, besides he was also a trainerof Kantau (silat) and the establisher of a college named Dente Sepuluh. Madi had a hut in the mountains which was also used as a place of treatment for the community, exactly Bolonggima (Salena II), Watumpanovahill. In his guesthouse, people came to the traditional treatment through balia traditional ceremony.

The absence of health care facilities and economic factors that did not support required Salena people to find other alternatives to do the treatment through their own way. Traditional medicine wasthe only way out for them. Madi which was believed to be the one who were able to heal the sick have became the hope of Salena society (even the society in neighboring hamlet that is Lekatu) to seek healing by seeing to him. His expertise as a shaman has made him popular among the Salena people and the Gawalise mountain range in general, even to the Buluri community.

On religious field, it was known that there were no religious leaders in the region. This is evidenced by the habits of Salena people who when performing the prayers and other religious activities they should call the Imam or religious leaders in the village of Buluri with a distance of about $3 \mathrm{~km}$ from Salena. Seeing these conditions, people in Buluri Village finally took the initiative to conduct religious guidance to the community Salena. The 
guidance was done so that they could get the knowledge in the field of religion, especially Islam.With this guidance, finally, some Salena people became mosque officials or Shara employees' and functioning when carrying out religious activities. Madi was also included in the board of the mosque (Shara employee) in Salena and appeared as one of the spiritual figures (Elite of Religion) although it can not be equated with a Kiai or Ulama.

The Islamic teachings practiced by Madi and his followers were a blend of original Islamic teachings with traditional beliefs. That was part of the mystical religious teaching as a local variation on the development of religious teachings. Madi's invitation to stick to the custom was also followed by most Salena communities. Their lack of knowledge about Islam was one of the factors influencing the development of an old culture containing animist values. The belief was growing especially in remote areas and isolated tribes such as in the Gawalise Mountains, including Salena.

In the implementation of Balia ritual of treatment, Madi, who played as Sando (shaman) was often possessed. The ritual was a magical ceremony that aimed at being a means of healing or rejection of a disease, the request of protection was to the supernatural power considered as a source of providers, safety, as well as could also provide havoc for humans. In the Balia treatment system, Sando's role was dominant because he acts as a person who communicates both directly and indirectly with the spirits of the ancestors and other magical powers. When a Sando is possessed by a spirit, all of his actions and deeds are about to change.In such conditions, Salena people believed that Madi is someone who has a special ability as a link between the human nature with the spirit realm. The spirits that often infest Madi while performing baliatreatment include: Spirit of Pue Bunggu (Huchbacked old woman) whose duty to give oath (baiat), Spirit of Pue Besi (old women) whose job is to convey about the teachings of Religion and Custom, and Spirit of Swordsman whose job is to give miracles to Madi.

Madi's position as Sando in the Salena community enabled him to gain followers from these circles. For six months running his teachings, Madi managed to gain as many as 90 heads of families to be his followers. Every follower of his teachings must perform the first loyal oath 'baiah' in order to be declared as truly holy and having appreciated customs, because the chaos felt by them all that time was due to their neglect of customs. For Madi, a person is considered sacred when willing to give loyal oath (following the oath to obey him as leader) and wearing a white headband.In addition, a follower's qualification to be called as having appreciated the customs was to use a yellow sash. After undergoing the oath and returning to the customary values taught, Madi told his group that they would one day live prosperously and there would be no more distress and disease. Unfortunately, the behavior of Madi and his followers by many parties directly was regarded as a teaching that deviates from Islamic values without first looking at the root of the problems surrounding the movement made by Madi and his followers. 


\section{Conclusion}

The plurality of the people of Central Sulawesi can be seen from the diversity of tribes, religions, and cultures of each of the community in that region. If the diversity is not properly considered, it can potentially lead to communal violence between one another, for example, the one that occurred in Poso and Salena. It can be said that the primary conditions that the led to the outbreak of communal violence in Central Sulawesi were: First, the urge of access of certain groups (mostly indigenous people) in terms of gaining power and resources. Second, the urge occuered through a process that was considered unfair and fraudulent. Third, the new rulers of the access and resources were the newcomers. Fourth, the ethnocentrism and exclusivism. Therefore, an inclusive, humane, and contextual diversity approach is needed to enable community integration that can be realized and the better social relationship can be established.

\section{References}

Ahimsa-Putra, HS. "Kemajukan Budaya, Komunikasi, dan Integrasi Nasional," in Journal of National Resistance, Vol. I. No. 1, April 1999.

Ainiyah, Nur. "Pembentukan Karakte Melalui Pendidikan Agama Islam," in al-Ulum. Vol. 13, No. 1, Juni 2013.

Azhar, M. "Masyarakat Kitab dan Pluralisme," in Journal of Tarjih, Vol. 11. No. 1, 2013.

Azra, Azyumardi, et al. "Pesantren and Madrasa: Muslim Schools and National Ideals in Indonesia," in Robert Hefner and Muhammad Qasim Zaman (ed.). Schooling Islam: the Culture and Politics of Modern Muslim Education. Princeton, New Jersey: Princeton University Press.

Bagir, Zainal Abidin, and Suhadi Cholil. The State of Religious Pluralism in Indonesia: ALiterature Review. Yogyakarta: Center for Religious and Cross-Cultural Studies, Gadjah Mada Univeristy, 2008.

Bernstein, R. "Cultural Pluralism," in Philosophy \& Social Criticism, 41 (4-5).

Cahyono, Heri. "Pendidikan Multikultural di Pondok Pesantren: Sebagai Strategi dalam Menumbuhkan Nilai Karakter," in At-Tajdid, Vol. 1. No. 1, Januari-Juni 2017.

Freedman, Amy, and Robert Tiburzi, "Progress and Caution: Indonesia's Democracy," in Asian Affairs: An American Review, 39, 2012.

Gillespiem, Piers. "Current Issues in Indonesian Islam: Analyzing the 2005 Council of Indonesian Ulama Fatwa No. 7 Opposing Pluralism, Liberalism, and Secularism," in Journal of Islamic Studies, 18 (2), 2007.

Gordon, Milton M. "Models of Pluralism: the New American Dilemma," in Annals of the American Academy of Political and Social Science, Vol. 454 March 1981. 
Hadi, Cholichul. et al. "Entrepreneurship and Education: Creating Business Awareness for Students in East Java Indonesia," in Procedia-Social and Behavioral Sciences, Vol. 177, Juli 2014.

Halidi, Leo Agustino. "Pemikiran Politik Lokal dalam Sejarah Pembentukan Provinsi Sulawesi Tengah," in Jurnal Analisis Politik, Vol. 1. No. 2, Maret 2016.

Hanik, U. "Pluralisme Agama di Indonesia," in Tribakti Journal, Vol. 25. No. 1. 2014.

Hassan, Riaz. "On Being Religious: Patterns of Religious Commitment in Muslim Societies," in The Muslim World, 97, (3) (July) 2007.

Hefner, Robert. "Islamic Schools, Social Movements, and Democratization in Indonesia," in Robert Hefner (ed.), Making Modern Muslims: The Politics of Muslim Education in Southeast Asia. Honolulu: University of Hawaii Press. Human Rights Watch, 2011.

Kaddi, Sitti Murni, et al. "Kerukunan Keluarga Sulawesi Selatan (KKSS) sebagai Forum Komunikasi dalam Penyelesain Konflik Etnis di Kota Palu," in Jurnal Komunikasi Kareba, Vol. 2. No.1 Januari-Maret 2013.

Kruijt, A.C. "Het Ijzer In Midden Celebes," in Journal of Bijdragen Tot De Taal-, Land-En Volkenkunde Van Nederlandsch-Indie, Deel 53, 1901.

Lestari, Gina. "Bhinnekha Tunggal Ika: Khasanah Multikultural Indonesia di Tengah Kehidupan Sara," in Jurnal Pendidikan Pancasila dan Kewarganegaraan, Vol. 28. No. 1, Pebruary 2015.

Mahid, H. "Kekerasan Massal dan Pluralitas Budaya," in Jurnal of Midden Celebes, Vol. 1. No. 2, 2012.

Ryandi. "Antara Pluralisme Liberal dan Toleransi Islam," in Kalimah Journal, Vol. 11. No. 2. 2013.

Said, Zainal. "Konflik Sosial Keagamaan Islam Non-Mainstream dalam Masyarakat Majemuk di Indonesia," in al-Ulum, Vol. 12, No. 2, Desember 2012.

Wekke, Ismail Suardi. "Integrasi Pendidikan Islam dan Pembelajaran Kewirausahaan di Pesantren Minoritas Muslim," in Fenomena, Vol. 9. No. 1, 2017.

Widiastuti. "Analisis Swot Keragaman Budaya Indonesia," in Jurnal Ilmiah Widya, Vol. 1 No. 1, 2013.

Zhao, Shuyan. "Theoretical Construction of Freedom and Pluralism Education in Pastoral Areas," in Journal International Education Studies, Vol. 2, No. 2 May 2009. 